\title{
The Geological History of the British Isles
}

G. M. BENNISON and A. E. WRIGHT

This outstanding new text synthesises the extremely large amount of recent literature and presents the reader with an up-to-date summary of the history of the area from earliest Precambrian times to the Pleistocene Period. The book is fully illustrated by II2 text-figures, many of them new compilations based on the most recent data and a large number of tables summarise data to which the student may frequently need to make reference. Extensive reading lists are presented to give the more important reviews and recent papers on each system. Cloth $\mathbf{£ 5 . 5 0}$ net Paper $£ 2.75$ net

\section{The Interior of the Earth}

M. H. P. BOTT

This book is mainly concerned with deep structure and mechanism and consequently details of surface geology have been kept to a minimum. The origins of the primary surface features such as ocean ridges, young fold mountains, trenches and rift valleys is described in relation to their deep structure and the ocean floor spreading hypothesis, but detailed description of them has not been given. It covers in particular those parts of geophysics which are particularly relevant to both geophysicists and geologists. With this in view the mathematical treatment has been omitted although indispensable formulae are included.

$£ 7.50$ net

\section{The Use of}

\section{Stereographic Projection in Structural Geography}

Third Edition

F. C. PHILLIPS

It is sixteen years since Professor Phillips first introduced his many readers to the stereographic technique as a means of describing three dimensional structures neatly, simply and speedily in two dimensions. In this time the unwieldy and complex traditional techniques involving the application of either descriptive geometry or trigonometry have receded into the background. This is the third edition, presented as an up-to-date introductory account of the subject at undergraduate level. Cloth $£ 2.20$ net Paper $£ 1.10$ net

\section{Edward Arnold}

\section{Hill Street, London W1X 8LL}




\section{GEOLOGICAL SOCIETY OF MALAYSIA Publications}

New/y Geological Map of The Malay Peninsula published ( $1: 100000$, coloured) compiled by D. J. Gobbett.

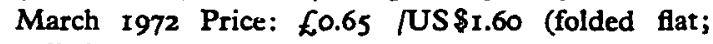
rolled extra at cost)

Abstracts of Papers: Regional Conference on the Geology of Southeast Asia, Kuala Lumpur, March 20-25, 1972. 64 pp., 8 figs., tables, many extended abstracts. February 1972 Price: $£ 1.00 /$ US \$2.40

(A selection of the papers from this Conference will appear in full in the Bulletin Series)

A/so Bulletin Series I968-. Bulletins I, 3, and 4 are collecavailable tions of papers on Malaysian geology; Bulletin 2 is an annotated Bibliography and Index of the Geology of West Malaysia and Singapore through 1967 (a Supplement for 1968 appears in Bulletin 3)

Bulletin 1 (1968): 79 pp. $£ 0.50 / U S \$ 1.20$

Bulletin 2 (1968): 152 pp. $£ 1.65 / U S \$ 4.00$ (paper) also in hard cover at $£ 2.45 / U S \$ 6.00$

Bulletin 3 (1970): r46 pp. $£$ r.65/US $\$ 4.00$

Bulletin 4 (197r): roo pp. $£$ r.65/US $\$ 4.00$

All prices include surface postage; for Air Mail, add an extra $£$ I.35/US\$3.40 for each Bulletin or Abstracts volume, and an extra $£ 0.45 / U S \$ 1.15$ for each copy of the map.

Other publications of the Society include a bi-monthly Newsletter, Presidential Addresses (1968-), and some miscellaneous papers, abstracts, and reprints (full list with prices on request).

\section{About the Society}

The GSM has a membership of about 300 geologists interested in Southeast Asia and the surrounding region. The membership is worldwide in distribution. Annual dues are $£ 2.45 / U S \$ 6.00$ and there is an entrance fee of $£ 0.85 /$ US $\$ 2.00$. The Society's publications are available to members either free or at reduced price.

The Society's Editor will gladly consider manuscripts on the geology of Southeast Asia or neighbouring regions, or on related and relevant topics, for publication in the Bulletin Series or as Short Notes in the Newsletter. For publication and map orders, write 'Publication Sales' at the address below.

For inquiries about the Society, membership, or prices of other publications write to 'The Honorary Secretary' at the address below.

THE GEOLOGICAL SOCIETY OF MALAYSIA c/o Department of Geology

University of Malaya

fuly 1972

Kuala Lumpur, MALAYSIA 


\section{RUSSIAN SCIENTIFIC JOURNALS}

The 1973 catalogue of technical and scientific lournals from the U.S.S.R. is now available.

Soviet journals are usually published in Russian but many have English summaries.

A Selected List:

\section{Geology Journal}

Ref. 741146 p.a. Annual sub. $£ 6.70$

Soviet Geology

Ref. 7082412 p.a. Annual sub. £13.35

Geology \& Geophysics

12 p.a. Annual sub. $£ 9.20$

Geotectonics

6 p.a. Annual sub. $£ 8.00$

Geochemistry

12 p.a. Annual sub. $£ 16.70$

Colleton Denington Wellingborough, U.K.

\section{Geological \\ Magazine}

is one of 48 learned journals published by Cambridge University Press.

A descriptive catalogue of Cambridge journals with details of back volumes is available from the London and New York offices of the Press.

Cambridge journals may be ordered from a bookseller or direct from the publishers.

\section{Cambridge University Press}

Bentley House, 200 Euston Road London, NWI 2DB

American Branch: 32 East 57th Street

New York, N.Y. 10022 


\section{NOTES FOR CONTRIBUTORS}

Articles submitted for publication in the Geological Magazine should be addressed to the editors at the Sedgwick Museum, Downing Street, Cambridge $\mathrm{CB}_{2}{ }_{3} \mathrm{EQ}$, England, and sent in duplicate. Publications for notice and review should be marked for the review editor at the same address.

Contributions, including reference lists, should be typewritten, double-spaced, and should be carefully revised. Where typing errors are corrected or minor alterations made, they should be done neatly in the typescript, leaving the margins clear. Marginal marks should be used only when correcting proofs. Illustrations should be drawn to allow reduction to a maximum size of $165 \mathrm{~mm} \times 11 \mathrm{omm}$; originals must not exceed $495 \mathrm{~mm} \times 33 \mathrm{omm}$ and must be sent in a flat package. Lettering must allow for legibility after reduction (i.e. equivalent to $1 \mathrm{~mm}$ as a minimum on reduction). Duplicates of illustrations may be prints or, preferably, reductions. Metric units of the SI system are preferred. Illustrations in the text will be referred to as figures (Fig. 2, 2a, etc.), and halftone plates will be referred to (also in arabic) as Plates 2, 2a, etc. Folding plates will not be accepted. Captions must be typed on separate sheets.

The typescript must be accompanied by a short summary. Contributors should follow the rules in the Geological Society of London's Notes to Authors (Proc. geol. Soc. Lond., No. I627, Oct. 1965), with the following exceptions. The total length of a paper should not in general exceed 20 pages of the Geological Magazine; preference and priority are given to short papers. Primary headings should be in lower case, at margin, with arabic numeral. Secondary headings should be in lower case italics (underlined), at margin, with Section number followed by lower case letter ( I.a, r.b, etc.). Tertiary headings should be in lower case italics (underlined), at margin, with Section number, lower case letter, and number of sub-section ( I.a.I, I.a.2, etc.).

No cross-references by page should be given to other parts of the text, but 'above' and 'below' used (with the section specified, e.g. 'Section 2 a $I$. '). References should be abbreviated in the form of the World List of Scientific Periodicals (4th edit., I963-65) as far as possible. e.g. Lapworth, C. 1878. The Moffat Series. Q. $7 l$ geol. Soc., Lond., 34, 240-343. Books should be cited briefly as: Burns, R. G. 1970. Mineralogical applications of crystal field theory. 224 p., C.U.P., London. Unpublished work, e.g. from theses, should normally be referred to in the text in parentheses and not included in the reference list unless already in the press. In the interests of authors, copyright is assigned to Cambridge University Press.

Twenty-five offprints of each article will be provided free of charge. Additional offprints may be purchased according to an agreed scale of charges. 


\section{Geological Magazine}

Volume 109, Number 3, May 1972

pages

BEAVIS, F.C.

The Manubriate Isograptids.

$193-204$

WALTHAM, A.C.

A contribution to the geology of the Annapurna and Nilgiri Himals, Nepal.

HEIMLICH, R.A., NELSON, G.C. \& MALCUIT, R.J.

Mineralogy of Precambrian Gneiss from the Bighorn Mountains, Wyoming.

CHAUDHURI, A.K.

Concise description of fold orientations.

ROBERTS, D.

Penecontemporaneous folding from the Lower Palaeozoic of the Trondheimsfjord region, Norway.

WRIGHT, J.B.

Tholeiite from the Cenozoic alkaline volcanic province of Nigeria.

PIDGEON, R.T. \& BOWES, D.R.

Zircon U-Pb ages of granulites from the Central Region of the Lewisian, northwestern Scotland.

DOWNIE, C. \& SOPER, N.J.

Age of the Eycott Volcanic Group and its conformable relationship to the Skiddaw Slates in the English Lake District.

HANCOCK, P.L.

The analysis of en-échelon veins.

\section{CORRESPONDENCE}

How old is silicate oxygen isotope geochemistry? Who were the pioneers? S. Viswanathan.

REVIEWS

(C) Cambridge University Press 1972

Printed in Great Britain by Alden \& Mowbray Ltd at the Alden Press, Oxford 